\title{
Habitat Preferences of the Grey Parrot in Heterogeneous Vegetation Landscapes and Their Conservation Implications
}

\author{
Simon A. Tamungang, ${ }^{1}$ Mathias A. Onabid, ${ }^{2}$ Taku Awa II, ${ }^{1}$ and Victor S. Balinga ${ }^{3}$ \\ ${ }^{1}$ Laboratory of Applied Ecology and Biology, Department of Animal Biology, University of Dschang, BP 67, Dschang, Cameroon \\ ${ }^{2}$ Department of Mathematics and Computer Science, Faculty of Science, University of Dschang, Mundemba, Cameroon \\ ${ }^{3}$ WWF Korup Project, P.O. Box 111, Limbe, South West Region, Cameroon
}

Correspondence should be addressed to Simon A. Tamungang; atamungang@yahoo.com

Received 6 October 2015; Revised 30 December 2015; Accepted 3 January 2016

Academic Editor: Stephan Koblmüller

Copyright (C) 2016 Simon A. Tamungang et al. This is an open access article distributed under the Creative Commons Attribution License, which permits unrestricted use, distribution, and reproduction in any medium, provided the original work is properly cited.

\begin{abstract}
The wild Grey Parrot Psittacus erithacus Linnaeus suffers from many habitat use challenges in the wake of extensive deforestation in its endemic range of West and Central African rainforests. To determine effects of these challenges on the bird species, seasonal densities of the Grey Parrot were determined using line transects in major heterogeneous vegetation types in the Korup Rainforest, south-western Cameroon. Results of the study highlight habitat preferences of this species on a seasonal base and under different situations of human activity intensity in the landscape. This information can be used to understand the causes of changes in the distribution and abundance of endangered species and also to determine sustainable conservation strategies. It is concluded that the parrot needs diverse vegetation types for survival in the wild state, as it depends on specific tree species for specific habitat resources such as food, roosts, security, and nests at specific periods of the year. Hence, the continuous survival of the Grey Parrot in the range states is not certain, if sustainable measures are not taken to conserve the parrot and its habitat resources both in and outside protected areas.
\end{abstract}

\section{Introduction}

Challenges of deforestation are major threats to sustainable wildlife conservation in tropical Africa. Despite the growing concern against forest destruction, the rate of loss has continued to increase [1]. Many studies indicate an annual tropical forest loss of over 20 million hectares, with a staggering 55.000 hectares per day $[2,3]$. In Sub-Saharan Africa, there are emerging severe environmental problems such as drought, which can jeopardize the well-being of individuals, populations, and even entire regional ecosystems $[4,5]$. Previous estimates indicated that Africa is losing from three to five million hectares of tropical forest each year [6]. In Cameroon, the forest covers a total area of about 20 million hectares, which is about $42 \%$ of the national area and is home to an enormous wildlife diversity including 938 species of bird [7]. These birds are closely associated with their habitats for various reasons, including foraging, security, and suitable breeding conditions.
Recent studies indicate that habitat selection by bird populations is closely associated with the level of coevolution and coadaptation shown by their interaction with components of the habitat [8]. For example, rainforest birds are known to be closely linked to their seasonal and annual breeding cycles. Similar studies have investigated the relationship between the structural complexity of habitats and bird species diversity [9]. Results of such studies can be used to predict the presence or absence of some bird species in particular habitat types. Similarly, from the work of Orians and Wittenberger [10], there is widespread evidence that the structural qualities of a habitat are paramount in determining occupancy by bird species. Birds therefore have emerged as highly specialized vertebrates which depend on their habitats and at the same time their habitats depend on them in many ways, thus forming an ecological web for survival. Yet, the destabilization of this ecological web can have devastating effects not only on birds alone but also on other living organisms including man. An important bird species that is closely linked to the 
rainforest in Africa is the Grey Parrot Psittacus erithacus Linnaeus.

The Grey Parrot inhabits primary and secondary lowland forests, wooded savannah, and montane forests of West and Central Africa [11]. Population declines of the bird have been noted in Burundi, Cameroon, Ghana, Guinea, Guinea-Bissau, Kenya, Liberia, Nigeria, Rwanda, São Tomé and Príncipe, Sierra Leone, Togo, Uganda, and parts of Congo and the Democratic Republic of the Congo. In all of these declines, trapping for the wild bird trade has been implicated, with habitat loss also having significant impacts throughout West and East Africa. The continuous loss of rainforest habitats is a major threat to the survival of the Grey Parrot in its endemic region. Populations declines have pushed the current conservation status of the parrot to vulnerable, as listed by the IUCN Red List of Threatened Species [12]. In Cameroon, for example, causes of habitat loss may vary from one part of the country to another, but they are mainly through timber exploitation, farming, and urbanisation. With the paucity of knowledge on the ecological role of the Grey Parrot in the rainforest ecosystem, it is difficult to foresee what the effect of decline of the bird species would be on the forest and the surrounding human communities. Nevertheless, the sustainable conservation of the Grey Parrot in African forests is crucial because the bird is an economic, nutritional, and aesthetic resource. In ecological viewpoint, the parrot is a frugivore which can directly or indirectly affect forest regeneration, resulting in climate change impacts. In other words, continuous rainforest degradation through unsustainable land-use practices can have direct effects on the ecology of Grey Parrot populations since the present vegetation destruction trends in Cameroon allow no considerations for habitat components that may be useful to the bird outside protected areas (National Parks, Wildlife Reserves, and Community Forests). Thus, this study determined seasonal densities of the Grey Parrot in relation to varying human activities intensities in three major vegetation types in the Korup Rainforest, south-western Cameroon. Results of the study can be used for effective landscape planning policy for the sustainable conservation of the parrot and its associated habitat resources in its endemic range of West and Central Africa $[6,9]$.

\section{Materials and Methods}

2.1. Review of Study Area and Previous Ornithological Work. The Korup Rainforest is located in the South West Region of Cameroon. The forest is made up of the Korup National Park and its support zone. The 125,000 ha National Park extends between latitudes $4^{\circ} 54^{\prime}$ and $5^{\circ} 28^{\prime}$ and longitudes $8^{\circ} 42^{\prime}$ and $9^{\circ} 16^{\prime}$. The support zone of the park is made up of three forest reserves (Rumpi Hills, Ejagham, and Nta-Ali), agricultural development, hunting, and watershed protection zones. The agricultural development zones include a 4,993 ha oil palm plantation contiguous with the south-western part of the park, owned by Pamol Plantation du Cameroun (Pamol du Cameroun). It is the largest monoculture agricultural establishment around the park area. The biggest urban area nearest to the park is Mundemba town, which is situated in the southern sector of the support zone and it is the administrative headquarters of Ndian Division.

The diverse avian species of Korup have over the years attracted the attention of both local and international ornithologists. European ornithologists started visiting the southern part of Korup as far back as 1801 [13]. Louette [14] has an extensive list of birds discovered in Korup and other parts of Cameroon in those early days. Some researchers have produced checklists of birds while working on other flora and fauna of the park. For example, Gartlan [15] produced a comprehensive checklist of birds while working on primates. Recent ornithological work in Korup includes that of the ICBP Team [16-20]. It has been estimated that 390 bird species live in the Korup National Park and its support zone [21]. The varied habitats offered by the montane forests, creeks, and estuaries increase avian diversity in Korup. In addition to the Grey Parrot, the Jardine's Parrot Poicephalus gulielmi also occurs in Korup.

2.2. Sampling Strategy. The Stratified Random Sampling [22, 23] was used to design the study site for data collection. This method ensured significant vegetation types representation through which line transects were randomly established. Three sampling units (sampling plots) were established based on the three major vegetation types of the study area (Figure 1), namely, primary vegetation, which was dominantly made up of pristine forest with very little or no socioeconomic activities; secondary vegetation, made up of patches of degraded forest and farmland; and a monoculture vegetation of palm oil plantation. Each sample plot had an average area of $35 \mathrm{~km}^{2}$. follows.

A brief description of the sample plots (Figure 1) is as

Park Sample Plot (PkSP). This plot was located within the southern part of the Korup National Park. It was bounded in the south by the Pamol Oil Palm Plantation (Figure 1). The plot was dominated by primary vegetation and thus minimal human activities (Figure 2(a)). Primary vegetation indicator species here included Protomegabaria macrophylla, Anthonotha fragrans, Erythrophleum ivorense, Xylopia aethiopica, Oubanguia alata, Dischostemma glaucescens, Strombosiopsis tetrandra, Afzelia bipindensis, and Enantia chlorantha.

Palm Sample Plot (PmSP). It was located in the palm oil plantation of Pamol du Cameroun (Figure 1). The Pamol Plantation is an agroindustrial development land for the production of palm oil products (Figure 2(b)).

The palm trees were of varying ages and planted in fields of 64 ha and were made of trees of the same age. Seven camps were constructed for workers in the plantation and offices built for plantation administration. Also, one primary school was located in the plot schools and another on the outskirts near the camps.

Mixed Sample Plot (MxSP). It was located in the agricultural development zone outside the Korup National Park (Figure 1) and next to the PmSP. It was the most heterogeneous plot in 


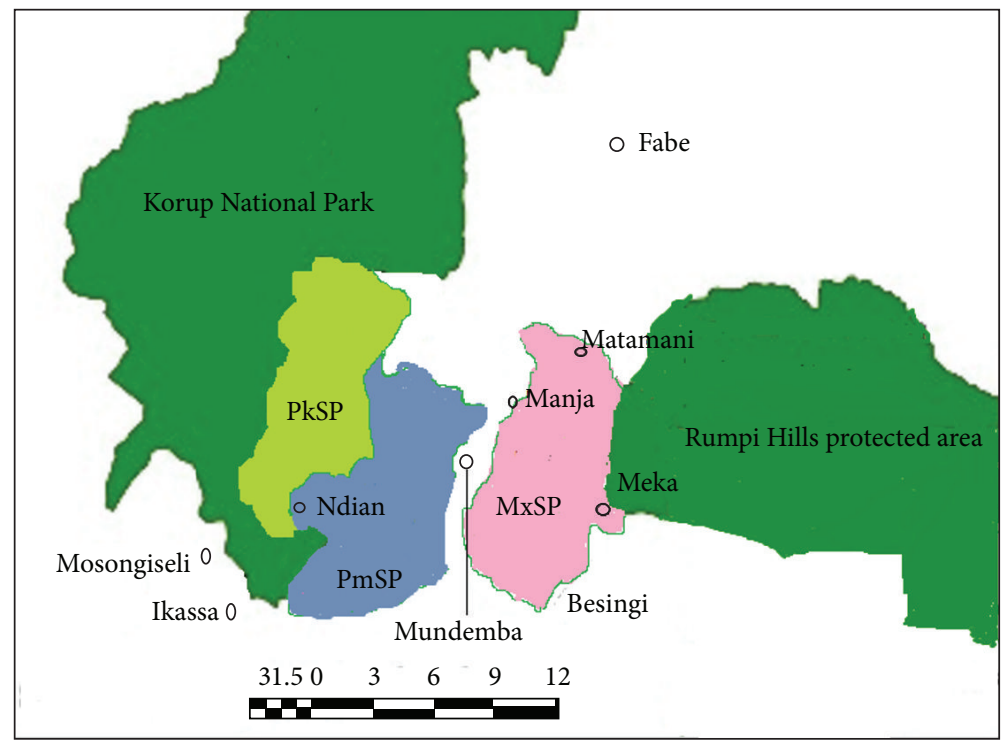

$\begin{array}{ll}\text { O : towns/villages } & \text { PmSP: Palms Sample Plot } \\ \text { PkSP: Park Sample Plot } & \text { MxSP: Mixed Sample Plot }\end{array}$

FIgURE 1: Sample plots layout for data collection in the southern part of the Korup Rainforest, South West Region, Cameroon.

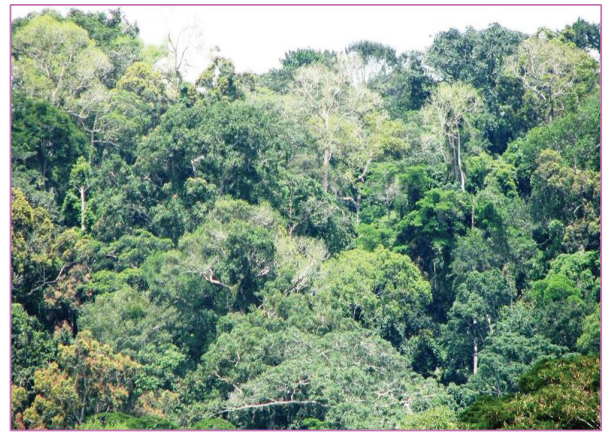

(a)

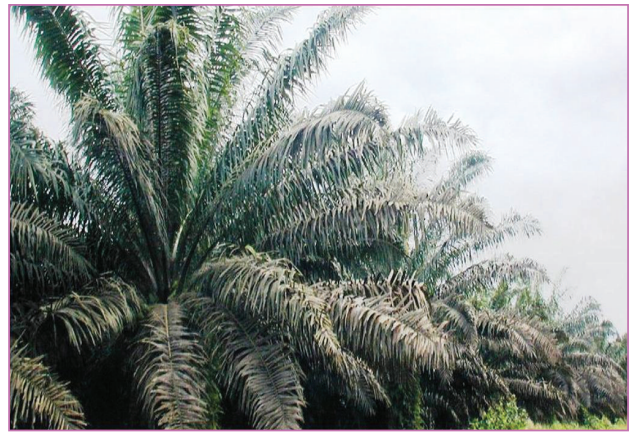

(b)

FIGURE 2: Typical vegetation types in sample plots: primary vegetation in the Park Sample Plot (a) and agricultural vegetation dominated by palm trees in the Palms Sample Plot (b).

terms of vegetation types as a result of land-based socioeconomic activities (Figure 3(a)). There were more human settlement sites in this plot than the Palm Sample Plot. Farming activities were prominent in the plot and the type of farming practiced was shifting cultivation (Figure 3(b)). Hunting, lumbering, and road construction were also carried out. The plot also had small scale plantations owned by individual farmers. Indicator tree species in this plot included Ceiba pentandra, Cordia aurantiaca, Melia excelsa, Musanga cecropioides, Pycnanthus angolensis, Terminalia superba, and Terminalia ivorensis.

2.3. Parrot Population Sampling. Parrots were sampled using line transects [22,23]. Transects were randomly established in each of the three sample plots. To avoid double data recording from neighbouring transects at short range, transects were fairly and widely spaced. They were also long enough to enable data collectors to go across a wider range of vegetation types, altitude ranges, and varied socioeconomic activities. Each transect had an average length of $3 \mathrm{~km}$. A total length of at least $42 \mathrm{~km}$ was covered in each sample plot in any data collecting session of two months. For more analytical use parrot detection distance on each transect was estimated at $0.25 \mathrm{~km}$ from the middle of all transects. Therefore, a total of $0.5 \mathrm{~km}$ was covered on both sides of each transect. All distances were estimated perpendicular to the transect line, rather than the distance from the bird to the observer [23]. Each transect was walked on foot during each session of bird count and walking distances were measured using a pedometer. Individual birds were directly counted as the main sampling technique $[23,24]$. In a situation where it was difficult to see birds especially in a dense tree canopy, indirect count (based on the song or call note of the bird) was used to mark the presence of the bird in the transect. Results of 


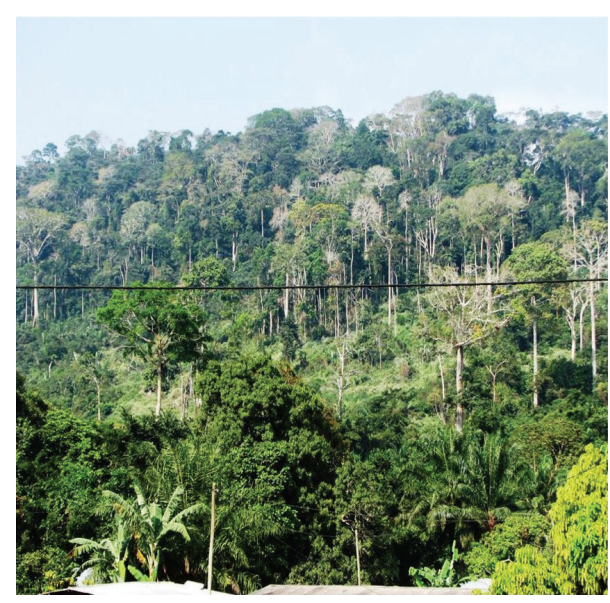

(a)

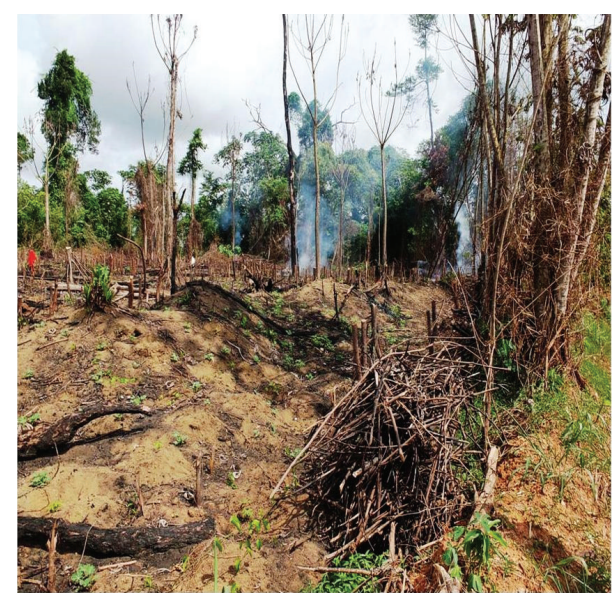

(b)

Figure 3: Typical vegetation type in the Mixed Sample Plot: patches of active, fallowing farmland, and degraded forest and agricultural tree species are shown in (a). Slash and burn farming practice is shown in (b). Note the smoke from the fire still burning in the background.

indirect counts were not used in the final calculations of the sample size.

The following assumptions were made during each sampling session:

(i) Birds within $0.25 \mathrm{~km}$ on each side of each transect were all detected.

(ii) Distances were measured accurately.

(iii) Individual birds were counted only once.

(iv) Birds were distributed randomly and independently over each transect.

(v) Sighting of individual birds was statistically independent events.

(vi) Bias from seasons, weather, and vegetation conditions were understood.

(vii) All data collecting sessions were treated equally.

For more sighting precision, a pair of binoculars (10x) was used and travelled distances on transects were measured using a pedometer. Parrot data collecting sessions were based on seasonality in the study area and data was collected as shown in Table 1.

Sampling started each day from $07 \mathrm{~h} 00$ to $10 \mathrm{~h} 00$ and from 14 h00 to 17 h00. A team of researchers sampled each transect three times during each dry and rainy season, over a period of 36 months.

2.4. Vegetation Sampling. Sample points were randomly established along transects within each sample plot for detail assessment of the impact of human activities on the vegetation. The number of sample points selected in each sample plot was made equal to the proportion of points in the area to be sampled [25]. Since all sample plots were about equal in size, an equal number of 20 sample points were obtained in each plot. A spacing distance of $1 \mathrm{~km}$ was used between sample points. The area and shape of each sample point were determined by modifying the standard circular sample plot of radius $12.62 \mathrm{~m}$ [25]. This reduced the edge effects of tracing a circular plot in the dense primary forest of the Park and Mixed Sample Plots. A $50 \mathrm{~m}$ tape was used to measure the perimeter of the point. A prismatic compass was used to ensure that the edges were straight. Edge tracing was carried out using a machete. Consecutive sample points were selected on alternate basis on each transect. This procedure was carried out to ensure that data collected was representative of a cross section of the vegetation of the sample plots. All sample points were treated equally throughout the study. Data was collected at all sample points with standard data sheets using the following parameters: major vegetation type, socioeconomic and development activities, canopy spread, girth of tree at breast height (gbh), and tree species diversity.

2.5. Data Processing. Parrot densities were obtained from the formula

$$
\text { Density }=\frac{\text { Number of individual animals }}{\text { Surface area occupied }} \text {. }
$$

Final datasets were synthesized and analysed using relevant available statistical packages. Nonparametric analyses, such as Chi-Squared test and Spearman's correlation, were used to establish pairwise comparisons of all the data collected from each sample plot and seasonal parrot densities.

These data were also pooled to estimate the mean $\pm \mathrm{SE}$ using Analysis of Variance (ANOVA); in addition, the oneway Analysis of Variance (ANOVA) was used to compare abundance in all the three sample plots over the period of study at the 0.05 level of significance. Where there was a significant difference statistically, Duncan's multiple range test was used to identify the cause of the difference. To find out if there was any interaction between sample plots and seasons, a two-way ANOVA test was carried out. 
TABLE 1

\begin{tabular}{lcc}
\hline Season & Abbreviation & Duration \\
\hline Early-dry season & EDS & October-November \\
Mid-dry season & MDS & December-January \\
Late-dry season & LDS & February-March \\
Early rainy season & ERS & April-May \\
Mid-rainy season & MRS & June-July \\
Late rainy season & LRS & August-September \\
\hline
\end{tabular}

\section{Results}

The Grey Parrot was observed in all plots and in all seasons. Parrot densities varied from a low value of $4.18 / \mathrm{km}^{2}$ to a high value of $64.71 / \mathrm{km}^{2}$ in single seasons. Figure 4 shows line plots of the mean densities of the concentration of Grey Parrots in the various sample plots during different seasons. On a general note, this display of the collected data shows a higher concentration of Grey Parrots during the dry season than in the rainy season.

3.1. Parrot Densities in Plots and Seasons. Concentrations in the PmSP were very high during the dry season but also very low during the rainy season. In fact, this plot had the highest value during the dry season as well as the lowest value during the rainy season. The MxSP had comparatively almost constant concentration of parrots during both the rainy and the dry seasons. The $\mathrm{PkSP}$ had lower values in both the rainy and the dry seasons when compared to the other plots.

Using one-way ANOVA to compare abundance in all the plots over the period of study, there was a significant difference between the plots. On using Duncan multiple range test to identify the cause of the difference, it turns out that the PkSP was the source of the difference while the Palm and Mixed Sample Plots showed no significant difference.

To investigate the possibilities of an interactive effect between seasons and sample plots, the two-way ANOVA test was carried out. This revealed a very significant interactive effect between different sample plots and different seasons.

A close look at Figure 4 shows the following trends in the sample plots.

Palm Sample Plot (PmSP). The lowest density of $10.5 / \mathrm{km}^{2}$ was recorded in the late rainy season and this was followed by $13 / \mathrm{km}^{2}$ in the mid-rainy season. Late dry season had the highest parrot density of $62.58 / \mathrm{km}^{2}$ and it is incidentally the highest during the study period. It was closely followed by the mid-dry season with $53.2 / \mathrm{km}^{2}$. A gradual density increase was observed from early-dry season through mid-dry season and then a drastic decrease from mid-rainy season to late rainy season.

Mixed Sample Plot (MxSP). Grey Parrot densities were generally high in this plot with the lowest value of $18.7 / \mathrm{km}^{2}$ in late rainy season, followed by late-dry season with $25.6 \mathrm{~km}^{2}$. The lowest parrot density is about three times greater than the lowest value in the Park Sample Plot. The highest value

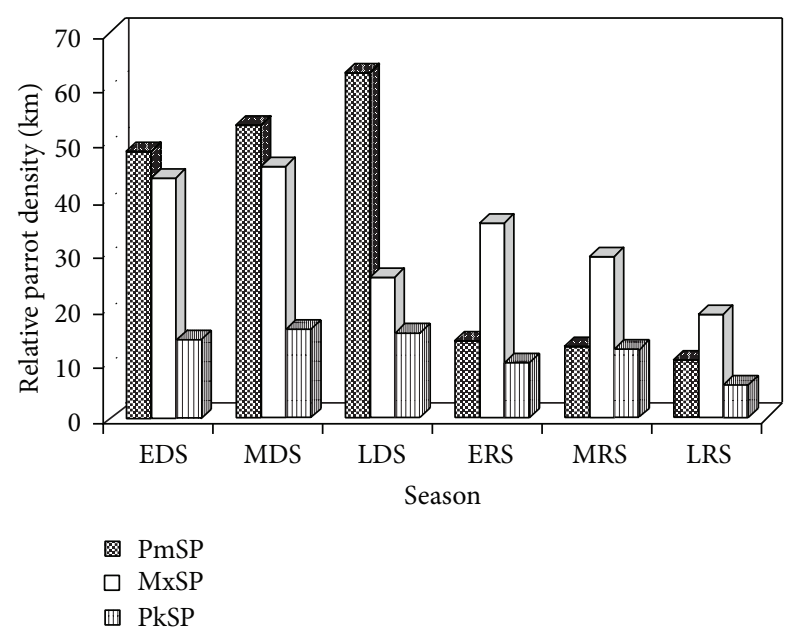

Figure 4: Mean relative densities of the Grey Parrot in seasons and sample plots for three years.

of $45.8 / \mathrm{km}^{2}$ was recorded during the mid-dry season and was closely followed by early-dry season with $43.5 / \mathrm{km}^{2}$. It should be noted that this same season (mid-dry season) had the highest density in the PkSP. Generally, there was no distinct difference in ranges observed between the seasons and parrot densities in the MxSP and hence parrot densities were marginally significant.

Park Sample Plot (PkSP). Seasonal densities were generally low in this sample plot. The lowest value of $6.04 / \mathrm{km}^{2}$ was followed by $10 / \mathrm{km}^{2}$ recorded in early rainy and late rainy seasons, respectively. However, the highest value of $16 / \mathrm{km}^{2}$ was recorded during the mid-dry season. This density was closely followed by late-dry season with a parrot density of $15.6 / \mathrm{km}^{2}$. A population density oscillation pattern was evident in this plot in which peaks were observed in the dry seasons and troughs in the rainy seasons. Seasonal densities were therefore not distinct but parrots were observed in all seasons during the study period. In a nutshell, parrot seasonal densities were marginally significant.

Figure 5 shows that the mean parrot densities were very variable in seasons. For example, Grey Parrots are most abundant in the study area during the mid-dry season and least abundant during the late rainy season. Seasonal distribution pattern shows that, after the peak value in middry season, the number of parrots dropped as the season advanced from dry to rainy periods. According to this grouping, mid-dry season, early-dry season, and late-dry season were significantly different from mid-rainy and late rainy seasons.

Overall seasonal mean (irrespective of the type of season) was $28.5 / \mathrm{km}^{2}$. Overall or total dry season (TDS) mean was $36.1 / \mathrm{km}^{2}$ and that for total rainy season (TRS) was $20.89 / \mathrm{km}^{2}$. In terms of percentages, TDS was $63.37 \%$ and TRS was $36.62 \%$ (Figure 5). Hence, a greater number of parrots were observed in the dry season. Annual population trends were very different from seasonal ones. A population increment rate of $7.9 \%$ was recorded for the study period of three years. 
TABLe 2: Mean densities of the Grey Parrot in sample plots in thirty-six months.

\begin{tabular}{lcccc}
\hline Sample plot & $\begin{array}{c}\text { Mean parrot } \\
\text { density } / \mathrm{km}^{2}\end{array}$ & Mean parrot density (\%) & Variance & $\begin{array}{c}N \\
\text { (total number of seasons) }\end{array}$ \\
\hline MxSP & $33.8 \pm 0.62$ & 38.8 & 20.52 & 13 \\
PkSP & $12.6 \pm 0.22$ & 14.4 & 2.75 & 13 \\
PmSP & $40.6 \pm 0.92$ & 46.6 & 42.25 & 13 \\
\hline
\end{tabular}

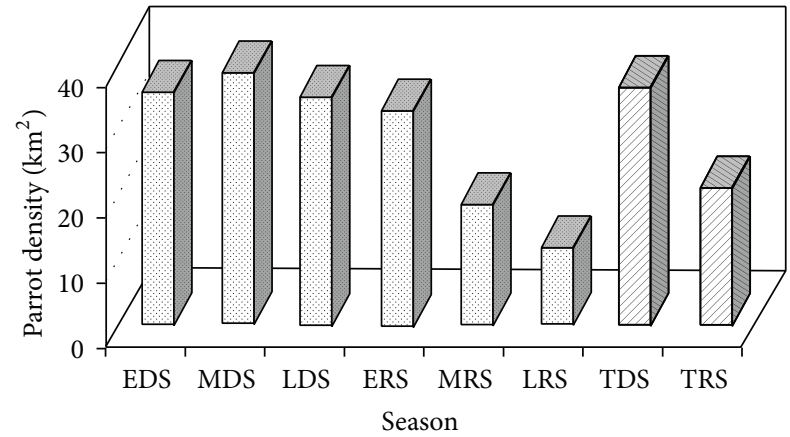

Figure 5: Mean abundance of the Grey Parrot per season in thirtysix months compared with total dry season (TDS) and total rainy season (TRS) abundance.

When the two major seasons (dry and rainy) were considered, total dry season (TDS) density was $38.4 / \mathrm{km}^{2}$ while total rainy season (TRS) was $20.9 / \mathrm{km}^{2}$. Similarly, an overall mean density was calculated for each sample plot and the Palm Sample Plot was the highest with $46.7 \%$, while the Park Sample Plot was the least with $14.5 \%$ and was significantly different from the other two plots (Table 2).

3.2. Impact of Human Activities on Vegetation. Each of the sixty sample points in the plots had at least seven trees of $5 \mathrm{~m}$ and above (Figure 6). The lowest number of trees per sample point was recorded in the PmSP where a regular pattern of tree density was also observed. This is contrary to the irregular trend observed in the MxSP and the PkSP with some sample points having very few trees and others with very high number of trees. Tree stand densities were generally the highest in the PkSP and each point had at least twenty tree stands (Figure 6). Although a significant difference was observed between the PkSP and the other two plots, there was no significant difference observed between sample points within each plot. Therefore, within a sample plot, tree stand distribution followed about the same pattern.

Basal area of trees at breast height was calculated from girths at breast height of trees in the sample points. The lowest basal area values were recorded in the MxSP. Means values for the PkSP, MxSP, and PmSP were $39.6 \mathrm{~m}^{2} / \mathrm{ha}, 32.6 \mathrm{~m}^{2} / \mathrm{ha}$, and $74.8 \mathrm{~m}^{2} /$ ha, respectively. Highest basal area values were observed in the Palms and Mixed Sample Plots. These mean values indicated that there was no much variation between the Palms and Mixed Sample Plots as compared to the low values. Analysis of variance showed a very high significant difference between the three sample plots.

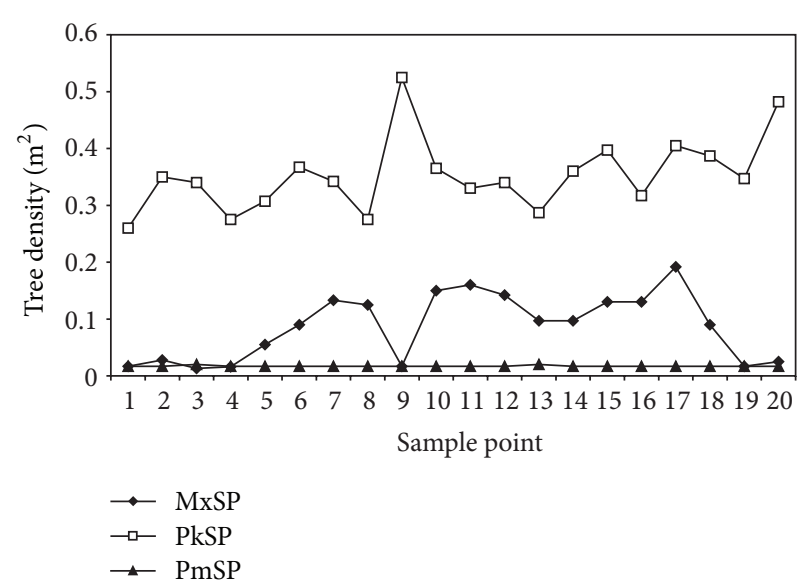

FIgURE 6: Comparison of tree stand density at sample points in sample plots.

Trees of height $5 \mathrm{~m}$ and above were summarised into $4 \mathrm{~m}$ class intervals (Table 3 ). The class frequencies obtained were further expressed as percentages of the overall frequencies in each plot.

It was generally observed that the number of trees decreased with increase in height class. The first two classes in all the plots had over $60 \%$ of all the height population sampled. For example, the MxSP had 70\%, the PkSP had $86.5 \%$, and the PmSP had 61\%. These figures show that the bulk of the trees measured in the sample plots were between the heights of $5 \mathrm{~m}$ and $14 \mathrm{~m}$. There were more tall trees in the $\mathrm{PkSP}$ than in the MxSP, as could be noticed between classes of 25-60 $\mathrm{m}$ and above. Very tall trees were fewer in the MxSP as compared to the PkSP.

\section{Discussion}

4.1. Effect of Seasonality on Grey Parrot Abundance in Sample Plots. We have been able to show that the abundance of the African Grey Parrot in the study area varied from day to day depending on the season and land use patterns that gave rise to various vegetation characteristics [26]. The Mixed Sample Plot had a relatively stable parrot density in all seasons. This stability could be attributed to the fact that this plot was a mixture of many vegetation types. Although dominated by secondary forest tree species, the plot was richer in food tree species than the other two plots. Seasonal changes in the Korup Rainforest phenology provide most of the habitat resources for the parrot [27]. Habitat preferences of the bird varied on a daily and seasonal basis and this was reflected in the distribution of the bird in plots. As such, $63.37 \%$ of 
TABLE 3: Frequency distribution of tree height in sample plots.

\begin{tabular}{|c|c|c|c|c|c|c|}
\hline \multirow{2}{*}{$\begin{array}{l}\text { Height class } \\
5 \mathrm{~m} \text { and above }\end{array}$} & \multicolumn{2}{|c|}{ MxSP } & \multicolumn{2}{|c|}{$\mathrm{PkSP}$} & \multicolumn{2}{|c|}{ PmSP } \\
\hline & $\begin{array}{c}\text { Number of } \\
\text { trees }\end{array}$ & $\%$ & $\begin{array}{c}\text { Number of } \\
\text { trees }\end{array}$ & $\%$ & $\begin{array}{c}\text { Number of } \\
\text { trees }\end{array}$ & $\%$ \\
\hline $5-9$ & 313 & 41.8 & 1856 & 64.8 & 42 & 30 \\
\hline $10-14$ & 211 & 28.2 & 620 & 21.7 & 44 & 31 \\
\hline $15-19$ & 114 & 15.2 & 141 & 4.9 & 49 & 34.5 \\
\hline $20-24$ & 56 & 7.2 & 123 & 4.3 & 7 & 4.5 \\
\hline $25-29$ & 23 & 3.1 & 58 & 2.0 & - & - \\
\hline $30-34$ & 12 & 1.6 & 21 & 0.7 & - & - \\
\hline $35-39$ & 9 & 1.2 & 18 & 0.6 & - & - \\
\hline $40-44$ & 7 & 0.9 & 8 & 0.3 & - & - \\
\hline $45-49$ & - & - & 8 & 0.3 & - & - \\
\hline $50-54$ & 1 & 0.1 & 5 & 0.2 & - & - \\
\hline 55-59 & 2 & 0.3 & 2 & 0.1 & - & - \\
\hline
\end{tabular}

the birds were observed in the dry season while $36.63 \%$ were observed in the rainy season.

Comparatively, very high densities of parrots were recorded in the PmSP during the dry seasons. In the rainy seasons, especially from July to October (mid to late rainy seasons) very low parrot densities were recorded in the PmSP. This period was characterised by very low atmospheric temperatures and heavy rainfall. As the seasons progressed from rainy to dry, temperatures gradually rose and the amount of rainfall gradually reduced. Parrot numbers were observed to increase in the same manner with the seasons in the PmSP.

The more stable parrot densities observed in the MxSP are evidence that it was a better alternative to the PkSP and the PmSP. Similar observations were made by Abensperg-Traun and Dickman [28] on the red-capped plover (Charadrius ruficapillus). They observed that habitat variables of this bird accounted for $63.4 \%$ of the total variation in bird numbers between plots. Major predictors of plover numbers were width and slope of the shore and orientations of plots. The palms provided only one type of food (palm fruits). Moreover, during breeding seasons the PmSP is virtually useless in the provision of nest cavities and so cannot be regularly visited.

4.2. Effect of Human Activities on of Vegetation Structure and Parrot Abundance. Trees are ultimate for the survival of Grey Parrots in the wild state. As arboreal bird species, their life style is dependent on specific tree species for specific habitat requirements. Parrots were observed to have special affinities for specific trees at specific seasons. No parrot was seen to come down from a tree to feed on the ground at any given moment throughout the study period of 36 months. This observation is contrary to observations made by May [29] in south-eastern Cameroon, where Grey Parrots frequently perch on the ground at rich mineral site to drink mineral water and feed on water weeds and soils (geophagy).

Variations of mean of tree densities in sample plots were very distinct. If high tree density determines occupancy by parrots, then the Park Sample Plot would have had the highest density of parrots, but this was not the case. The only type of tree the parrot can use in the PmSP is the oil palm tree, on which it feeds on the fruits, roosts, and plays on the crown. The MxSP harbours the most diverse tree species in the Korup region, though occurring in patches due to landbased socioeconomic activities. This plot had the highest stable parrot density followed by the Palm Sample Plot. Habitat preferences of the Grey Parrot tend to favour trees species diversity more than tree density. This observation confirms an earlier observation in the same study area that food diversity tends to have more adaptive value to the Grey Parrot abundance of only one food source like the oil palm fruit at a given season [27].

Similarly, crown closure in the Palms and Mixed Sample Plots was influenced by land-based socioeconomic activities at different levels and his favoured parrot abundance. The least number of tree stands per unit area was recorded in the Palms Sample Plot while the highest was recorded in the park area. Judging from this result, if it is the number of trees that attracts more parrots in a sample plot, then the park would have had by far more birds than the other two plots. Overall bird densities in sample plots indicate that the park had the least number of birds. For example, vigilance against predators was better in open farmland with scanty trees than in close forest of the park. The Mixed Sample Plot had a more stable parrot density throughout the study period and was closely followed by the palms. On seasonal basis, the Mixed Sample Plot dominated in the rainy season and the Palms Sample Plot in the dry season.

A closer look at parrot interaction in the sample plots revealed the following.

Park Sample Plot. The park harbours over a hundred of tree species since socioeconomic activities are kept at a minimal level to promote sustainable biodiversity conservation [3032]. The Mixed Sample Plot, being a mixture of all vegetation types in the region, has even more tree species than the park. McCollin [32] made similar observations on the role of habitat structure in birds. 
Crown closure in the Park Sample Plot was very dense and continuous and this was broken in some places by emergent species and/or windfall. Cody [33] described similar vegetation structure and showed how it influences bird species competition and productivity. It was also observed that the parrot preferred to move from branch to branch using its hooked beak to support its body weight rather than making short flights on the same tree. The parrot was generally found in areas of gap formation and isolated sites of very tall trees. These sites are preferred as they enhanced security abilities of the bird. A parrot perching on a tree crown preferred a vantage point where it could see and monitor what was happening in its vicinity.

Revisits to particular foraging sites by the parrot were very unpredictable and depended on availability of habitat resources. There was also a tendency for particular sites to be used and abandoned for many years later, suggesting that important habitat resources of the bird may not be found in the same place many times for many years or this change in behaviour can also be attributed to insecurity. Park Sample Plot was generally an unstable habitat and marginally used by the parrot although socioeconomic activities here were relatively minimal.

Palm Sample Plot. Crown closure pattern was similar throughout the plot as the dominant tree species was the oil palm (Elaeis guineensis). As such, there was very little variation in microhabitats when compared to the other plots. Gaps were found in areas with roads and young palms and under mature palms. This plot was highly preferred by the Grey Parrot in the dry season. This plot did not provide nest cavies for breeding but provided food, shelter, and roosts. The parrot could easily move in the palm tree crowns since they were void of vines and only small epiphytes were sometimes present. Small epiphytes that grow on palm tree stems were orchids (Diaphananthe, Platycerium), bromeliad (Billbergia), and ferns (Drynaria) which were regularly cleared when oil palm nuts were being harvested. The parrot used this space by flying under palms for short distance and over them for long distances. Palms were about the same height and stems were evenly spaced. These features increased vigilance distances of the bird when flying under or over the palm tree canopy.

Mixed Sample Plot. This was the most heterogeneous habitat in terms of tree species diversity and structure as a result of land-based diverse socioeconomic activities. These variations enhance a more dynamic habitat type with most favourable conditions for the Grey Parrot in the study area. Crown closure ranged from very low to very high values. Epiphytes and lianas were present in forest patches, minimally present in fallowing farm and completely absent in most active farms. The parrot preferred generally tall isolated trees with few fresh leaves and perched at vantage points on branches. This position enhanced its vigilance abilities from predators since crown spread was minimal. The presence of many secondary tree species such as Terminalia superba, Ceiba pentandra, Pycnanthus angolensis, and Musanga cecropioides provided unique habitat resources to the parrots for food, nests, and roosts. Food crop tree species such as plums and guavas were exclusively found on this plot $[34,35]$.

All classes of tree heights in the region were present in the Mixed Sample Plot. As such the parrot had to select the preferred height at any time of the year. This factor might have contributed to the high and stable parrot densities throughout the study period. In a similar study, Keast [31] found out that the presence of a specific kind of vegetation was important in determining the presence and abundance of some bird species. Bird feeding patterns on trees were related to tree height and the nature of food type found on it. The Grey Parrot is limited in distribution to African lowland rainforest. Characteristically, these forests have very high rainfall. As a result, they are most of the time wet, especially areas below tree canopies. The parrot has been observed to be a very clean bird which prefers to perch on dry and clean portions of a tree. Similar observations were made by Suárez-Seoane et al. [8] in Spain on large agricultural Steppe birds. Different bird species therefore use different tree heights in different ways determined by their evolutionary history as a survival strategy $[33,34]$.

The Grey Parrot tends to have more affinity for one type of habitat at particular periods of the year than the other. Parrot density in the Mixed Sample Plot remained relatively stable over the years. This is an indication that this habitat is able to provide most of the habitat requirements of the bird during the varying seasons of the year. This plot provided a majority of nesting sites, roosts, and food types compared to the rest of the plots. Similarly, the Western king bird (Tyrannus verticalis) exhibits different patterns of habitat use at different spatial scales. Keast [31] examined the relationship between habitat structure and habitat use by the Western king bird. He observed that this bird is highly selective in microhabitat, using only a subset of the available habitat type. In contrast, the bird was less selective within macrohabitats. There were few significant differences between used and unused territories. Fry et al. [11] observed that a major interesting feature of rainforest avifauna is the degree of coevolution and coadaptation shown by birds and plants. Indeed, rainforest birds are closely linked with their habitats which to a certain extent also depend on them [5].

4.3. Implications of Land Use Patterns on Grey Parrot Conservation. Land-based socioeconomic activities affect the composition and distribution of vegetation on which parrots depend for food, breeding, and shelter. A majority of these activities take place outside the Korup National Park (in the support zone) such as farming, logging, road construction, and urbanisation.

The Korup National Park is state land and a first class protected area in Cameroon. This is the contrary in the support zone where each village claims a traditional authority over land surrounding such a village. Most people of the area depend on mixed subsistent and cash crop economy which tends to increase socioeconomic pressure on forest resources.

These land use patterns have resulted in high vegetation heterogeneity in the Korup region. Vegetation heterogeneity results in an uneven distribution of habitat resources for the parrot. Diverse vegetation types are therefore important 
for the survival of the Grey Parrot in the wild state. As an arboreal bird species, its lifestyle is dependent on specific tree species for specific habitat needs at specific periods of the year $[26,34]$. For this reason, about $80 \%$ of the bird population is found in the support zone of the park. This study has shown that highly used habitats by the Grey Parrot are secondary forests and farmland, which have interspersed diversity of tree species. The primary forest, dominantly found inside the national park, is marginally used by the bird. These highly used areas outside the park are also highly used for landbased socioeconomic activities. The parrot feeds heavily on many economic crops such as plums and oil palm fruits. Its feeding methods on these fruits are rather destructive and thus a cause for concern to the farmers. The park area is an ideal site for the conservation of the parrot alongside other wildlife resources, but this is not the case as shown by this study. The dominant presence of the parrot outside the park area faces a serious conservation threat as the bird is exposed to poaching and habitat threats compared to that inside the park area. The dominant presence of the parrot outside the park area makes it more vulnerable to poaching activities. The foregoing observations point to the fact that the continuous survival of the Grey Parrot in the range states is not certain, if sustainable measures are not taken to conserve the parrot and its habitat resources outside protected areas.

\section{Conclusion}

Land use patterns for socioeconomic reasons gave rise to differences in vegetation structures observed in the Korup Rainforest. Such vegetation structures influenced selection preference and effective use of each habitat type in various seasons by the Grey Parrot. The parrot depends on specific tree species for specific habitat resources at specific periods of the year. The most preferred vegetation types (secondary forests and farmland) offered most of these habitat resources. The park area is an ideal site for the conservation of the parrot alongside another wildlife, but this study showed that it is least used by the parrot since about $80 \%$ of the bird population was found in the support zone of the park. Hence, the continuous survival of Grey Parrot in the wild is not certain, if sustainable measures are not taken to conserve this bird and its associated habitat resources outside protected areas. Consequently, the continuous survival of the parrots is dependent upon the degree of support derived from the local communities in and outside conservation areas and the integration of parrot conservation policies in land use policies of the state.

\section{Disclosure}

Victor S. Balinga served as Manager of the defunct WWF Korup Project.

\section{Competing Interests}

The authors declare that there is no conflict of interests regarding the publication of this paper.

\section{Acknowledgments}

Immense thanks are due to the personnel of the Korup National Park, Pamol du Cameroon, and villagers of Ndian Division who assisted the authors' research team in many ways during field data collection. Gilbert Mofor, Edwin Penn, and Ernest Achu and all of PARROTPRO Research Group assisted in data collection.

\section{References}

[1] D. Sheil and M. Van Heist, "Ecology for tropical forest management," International Forestry Review, vol. 2, no. 4, pp. 261-270, 2000.

[2] S. N. Seo, R. Mendelsohn, A. Dinar, R. Hassan, and P. Kurukulasuriya, "A ricardian analysis of the distribution of climate change impacts on agriculture across agro-ecological zones in Africa," Environmental and Resource Economics, vol. 43, no. 3, pp. 313-332, 2009.

[3] Food and Agricultural Organization (FAO) of the United Nations, "FRA 2000 terms and definitions," Forest Resource Assessment Programme Working Paper 1, Food and Agricultural Organization (FAO) of the United Nations, Rome, Italy, 1998.

[4] S. D. Torti, P. D. Coley, and T. A. Kursar, "Causes and consequences of monodominance in tropical lowland forests," The American Naturalist, vol. 157, no. 2, pp. 141-153, 2001.

[5] D. Lamb, P. D. Erskine, and J. A. Parrotta, "Restoration of degraded tropical forest landscapes," Science, vol. 310, no. 5754, pp. 1628-1632, 2005.

[6] K. Boahene, "The challenge of deforestation in tropical Africa: reflections on its principal causes, consequences and solutions," Land Degradation \& Development, vol. 9, no. 3, pp. 247-258, 1998.

[7] Global Forest Watch (GFW) Cameroon, "An overview of logging in Cameroon," A Global Forest Watch Cameroon Report, World Resources Institute, Washington, DC, USA, 2000.

[8] S. Suárez-Seoane, P. E. Osborne, and J. C. Alonso, "Largescale habitat selection by agricultural steppe birds in Spain: identifying species-habitat responses using generalized additive models," Journal of Applied Ecology, vol. 39, no. 5, pp. 755$771,2002$.

[9] K. K. Joshi, D. Bhatt, and A. Thapliyal, "Avian diversity and its association with vegetation structure in different elevational zones of Nainital district (Western Himalayan) of Uttarakhand," International Journal of Biodiversity and Conservation, vol. 4, no. 11, pp. 364-370, 2012.

[10] G. H. Orians and J. F. Wittenberger, "Spatial and temporal scales in habitat selection," American Naturalist, vol. 137, pp. S29-S49, 1991.

[11] C. H. Fry, S. Keith, and K. E. Urban, The Birds of Africa, vol. 3, Academic Press, London, UK, 1988.

[12] BirdLife International, "Psittacus erithacus. The IUCN Red List of Threatened Species 2013," 2013.

[13] W. Serle, "Some breeding bird records at Indian, British Southern Cameroons," Nigerian Field, vol. 24, pp. 76-79, 1959.

[14] M. Louette, "The birds of Cameroon: an annotated checklist Brussels," Verhandeling Wetenscheeppen Jaargang, vol. 43, no. $163,1981$.

[15] S. G. Gartlan, Korup Regional Management Plan: Conservation and Development in Ndian Division of Cameroon, Publications 
25-106, Wisconsin Regional Primate Research Centre, Madison, Wis, USA, 1984.

[16] S. N. Sturt, "Records of other species of birds from Western Cameroon," in Conservation of Cameroon Montane Forests, S. N. Sturt, Ed., pp. 106-129, International Council for Bird Preservation, Cambridge, UK, 1986.

[17] T. H. Gullick, "List of birds seen in the Korup National Park," Report, 1987.

[18] J. Adison, P. Casman, D. Counsell, T. Thomas, and R. Wolton, "A brief survey of birds, and other small mammals and water beetles in Korup National Cameroon Park, by a visiting British Team," Report, 1988.

[19] "Project raleigh bird survey in Korup National Park. Phases 1-3," Tech. Rep., 1989.

[20] J. Thomas, "Birds of Korup National Park, Cameroon," Malimbus, vol. 13, pp. 11-23, 1991.

[21] P. G. Rodewald, P. A. Dejaifve, and A. A. Green, "The birds of Korup National Park and Korup Project Area, Southwest Province, Cameroon," Bird Conservation International, vol. 4, pp. 1-68, 1994.

[22] B. Husch, C. I. Miller, and W. T. Beers, Forest Mensuration, John Wiley \& Sons, Toronto, Canada, 3rd edition, 1982.

[23] W. J. Sutherland, The Conservation Handbook: Research, Management and Policy, Blackwell Scientific, Oxford, UK, 2000.

[24] C. J. Bibby, N. D. Burgess, D. A. Hill, and S. H. Mustoe, Bird Census Techniques, Academic Press, London, UK, 2nd edition, 2000.

[25] S. S. Rosenstock, D. R. Anderson, K. M. Giesen, T. Leukering, and M. F. Carter, "Landbird counting techniques: current practices and an alternative," Auk, vol. 119, no. 1, pp. 46-53, 2002.

[26] M. Galetti, "Diet of the scaly-headed parrot (Pionus maximiliani) in a semideciduous forest in southeastern Brazil," Biotropica, vol. 25, no. 4, pp. 419-425, 1993.

[27] S. A. Tamungang and S. S. Ajayi, "Diversity of food of the grey parrot Psittacus erithacus in Korup National Park, Cameroon," Bulletin of the African Bird Club, vol. 10, no. 1, pp. 33-36, 2003.

[28] M. Abensperg-Traun and C. R. Dickman, "Distributional ecology of red-capped plover, Charadrius ruficapillus (Temminck, 1822), on Western Australian salt lakes," Journal of Biogeography, vol. 16, no. 2, pp. 151-157, 1989.

[29] D. L. May, "Grey parrots of the congo basin forest," PsittaScene, vol. 13, no. 2, 2001.

[30] M. De Cáceres, P. Legendre, R. Valencia et al., "The variation of tree beta diversity across a global network of forest plots," Global Ecology and Biogeography, vol. 21, no. 12, pp. 1191-1202, 2012.

[31] A. Keast, "Tropical rainforest avifauna: an Introductory Conspectus," in Conservation of Tropical Forest Birds, vol. 4 of ICBP Technical Publication, pp. 3-32, 1985.

[32] D. McCollin, "Forest edges and habitat selection in birds: a functional approach," Ecography, vol. 21, no. 3, pp. 247-260, 1998.

[33] M. L. Cody, "Habitat selection in birds: the roles of vegetation structure, competitors, and productivity," BioScience, vol. 31, no. 2, pp. 107-113, 1981.

[34] T. M. Bergin, "Nest reuse by western kingbirds," The Wilson Bulletin, vol. 109, no. 4, pp. 735-737, 1997.

[35] S. A. Tamungang, R. A. Cheke, G. Z. Mofor, R. N. Tamungang, and F. T. Oben, "Conservation concern for the deteriorating geographical range of the grey parrot in Cameroon," International Journal of Ecology, vol. 2014, Article ID 753294, 15 pages, 2014. 

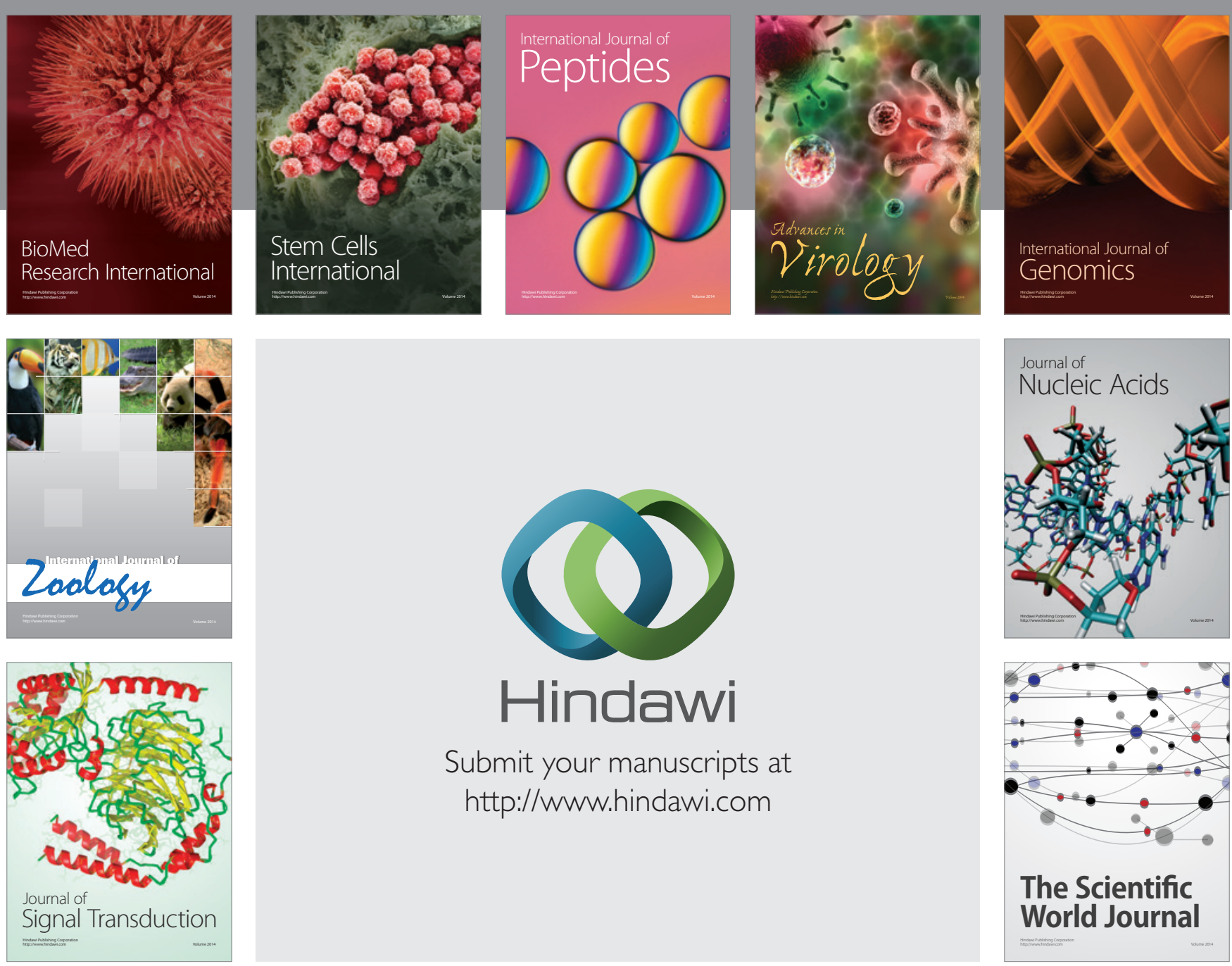

Submit your manuscripts at

http://www.hindawi.com
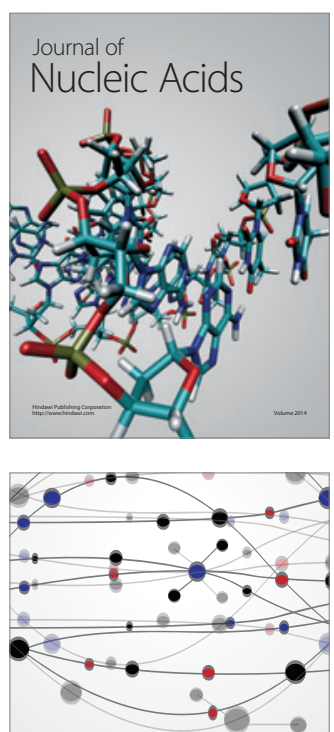

The Scientific World Journal
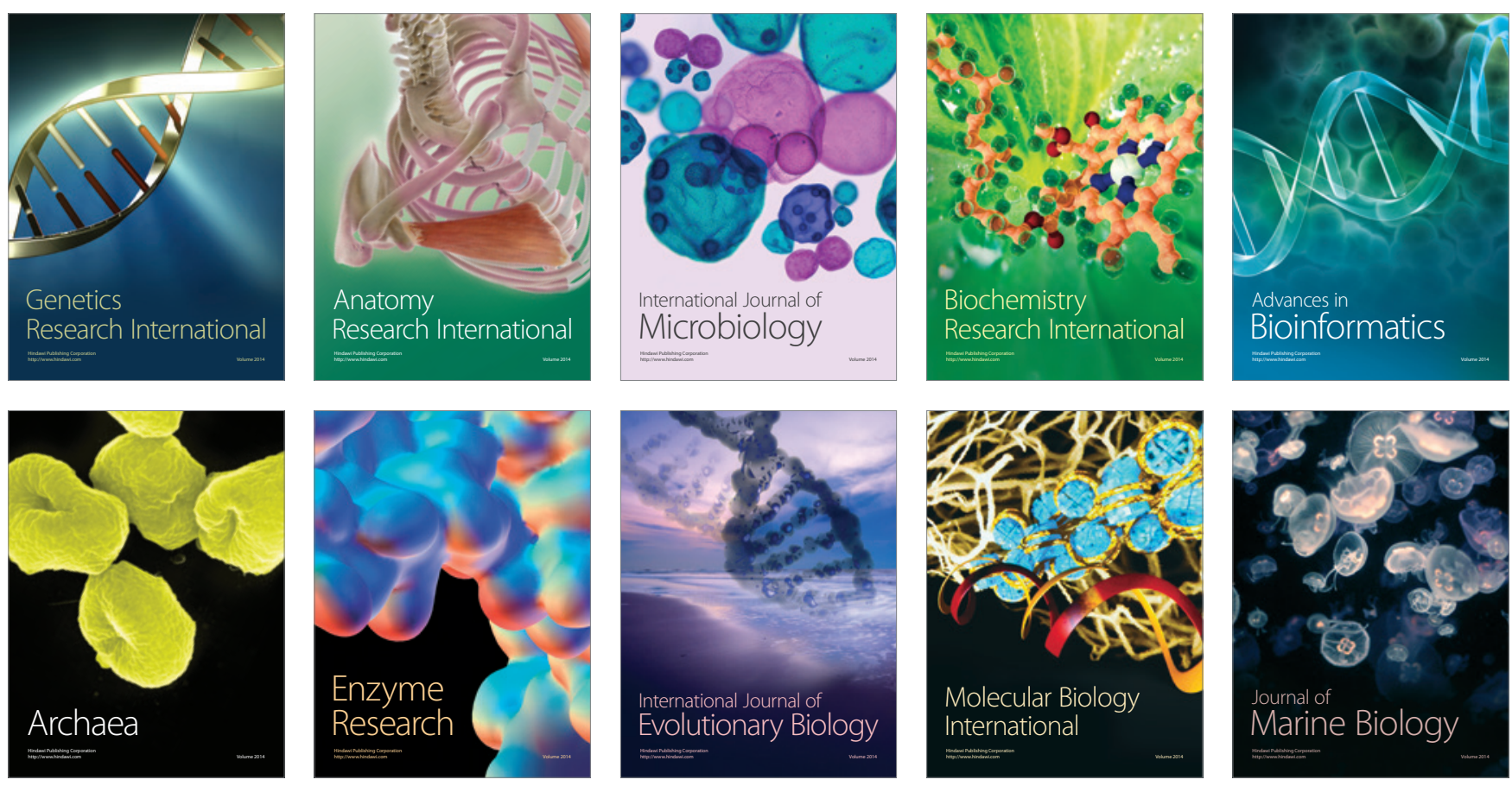